\title{
Application of nano- and micro-sized particles of cattle manure on soybean growth
}

\author{
Hesam Aryanpour ${ }^{1}$, Seyed Alireza Movahedi Naeini ${ }^{1 *}$, Ahmad Ahmadian ${ }^{2}$ \\ ${ }^{1}$ Department of Soil Sciences, School of Agriculture, Gorgan University of Agricultural Sciences and Natural Resources, Gorgan, Iran \\ ${ }^{2}$ Department of Medicinal Plant, School of Agriculture, University of Torbat Heydariyeh, Torbat Heydariyeh, Iran
}

\begin{abstract}
Background: Cattle manure (CM) is the most common organic fertilizer used by farmers. However, its usually slow decomposition leads to the use of chemical fertilizers. Therefore, experiments on nano- and micro-sized particles of CM were conducted to evaluate the possibility of accelerating its decomposition in soil.

Methods: The effects of a sole application of CM in different sizes (nano-, micro-, and natural-sized particles) in two ranges ( 5 and $20 \mathrm{Mg} \mathrm{ha}^{-1}$ ) and the combined application of $\mathrm{CM}$ and chemical fertilizers on the plant growth characteristics of soybean (cv. JS 335) were studied at Gorgan University. Nano- and micro-sized particles of CM were produced using a ball mill, and their half-life in soil was measured. Soil properties were measured before planting. Grain yield, 1000 grain weight, number of pods per plant, biological yield, plant height, and nutrient contents in plant shoot material were measured.

Results: The results showed that the use of nano-sized particles of CM (nCM) caused a significant increase in yield and yield components. Increasing the amount of crushing resulted in an increased rate of CM mineralization and in proper nitration before the formation of nodes in the roots. A significantly higher yield was obtained with nCM than with chemical fertilizer, and due to the nCM particles' half-life in soil, the plants were allowed to absorb nutrients for a longer time period.

Conclusion: The nCM has two major advantages over chemical fertilizers in that it does not release nutrients as quickly as chemical fertilizers and the loss of nutrients from soil is low.

Keywords: Manure, Nitrogen (N), Phosphorus (P), Potassium (K)

Citation: Aryanpour H, Movahedi Naeini SA, Ahmadian A. Application of nano- and micro-sized particles of cattle manure on soybean growth. Environmental Health Engineering and Management Journal 2017; 4(4): 239-244. doi: 10.15171/EHEM.2017.33.
\end{abstract}

Article History:

Received: 9 August 2017

Accepted: 25 September 2017

ePublished: 12 October 2017

\section{Introduction}

Soybean (Glycine max) is one of the most valued oilseed crops in the world. The origin of soybean cultivation is China. In the US Corn Belt region, soybean yield potential has been estimated to be in the range of 6-8 $\mathrm{Mg} \mathrm{ha}^{-1}(1,2)$. Per hectare, a soybean crop yielding $2.5 \mathrm{t}$ seed removes about $125 \mathrm{~kg}$ nitrogen $(\mathrm{N}), 23 \mathrm{~kg}$ phosphorus, and $101 \mathrm{~kg}$ potassium (K) from the soil (3). Thus, soybeans need to add nutrients to their desired function. This requirement is usually met by adding both organic and chemical fertilizers. However, these soluble fertilizers are also very mobile in the soil, and a large portion often ends up in surface- or groundwater bodies through runoff or seepage, causing groundwater contamination and eutrophication. On the other hand, organic forms of nutrients (e.g., cattle manure $[\mathrm{CM}]$ ) have also been attempted as fertilizers, where the nutrients are locked in an organic form and are less effective in providing nutrients at the critical time (when the plants are in need).
In light of these problems related to the application of conventional fertilizers, nano-sized particles of CM can be used.

$\mathrm{CM}$ nanoparticles (nCM) were evaluated as a potential fertilizer to improve nutrient efficiency based on the hypothesis that nano-sized particles can potentially mineralize in the soil faster than CM. These nanoparticles are very small, ranging in size from $1 \mathrm{~nm}$ to $100 \mathrm{~nm}$, with 1 $\mathrm{nm}$ being about 10000 times smaller than the diameter of a human hair. These very tiny particles have large specific surface areas and high reactivity; they are quite fantastic to a variety of applications in various fields, including agriculture (4-6). Recent studies have had promising results on hydroxyapatite nanoparticles as P fertilizer $(7,8)$. Liu and Lal reported that with the use of hydroxyapatite nanoparticles, the growth and yield of soybeans increased by $33 \%$ and $20 \%$, respectively, compared with phosphorus solid fertilizers. This is probably due to the greater mobility and more reactive levels of nanoparticles that 
allow solubility and further release of phosphorus (9). Organic manures cannot alone meet the heavy demand for nutrients in intensive soybean production because of their limited availability and restricted nutrient supply (10). On the other hand, chemical fertilizers are completely soluble in water, and a large portion often ends up in surface- or groundwater bodies, and are, thus, not fully absorbed by the plant. There is a need to find new products and new ways of supplying nutrients, while at the same time minimizing environmental impacts. This study reports the impact of synthesized nano-sized CM as a class of fertilizers to enhance the growth and yield of soybean through a field study. Nano- and micro-scale experiments were conducted to evaluate the possibility of accelerating the decomposition of CM in soil. The main goal of this study was to investigate the potential benefits of CM and its nanoparticles and microparticles incorporated into top-soil on soybean yield through a field study.

\section{Methods}

Preparation of nano- and micro-sized particles of cattle manure

In this study, nano- and micro-sized particles of CM were produced using a ball mill, one of the most powerful tools in industrial-scale production of nanoparticles. Coarse particles of manure were crushed in the collision of highenergy balls to become nanoparticles. The nano- and micro-sized particles prepared using the ball mill machine were spherical in shape with diameters of $70 \mathrm{~nm}$ and 2.5 $\mu \mathrm{m}$, respectively. The chemical composition was pure CM. To verify particle size, sample photos were taken using scanning electron microscopy (Figure 1).

\section{Description of the study area}

A field experiment was conducted during 2015 at the research farm of Gorgan University of Agricultural Sciences and Natural Resources, Gorgan, Iran (approx. $37^{\circ} 45^{\prime} \mathrm{N}, 54^{\circ} 30^{\prime} \mathrm{E}$; altitude $13 \mathrm{~m}$ A.S.L.). The region has a temperate climate and receives $601 \mathrm{~mm}$ annual rainfall.

\section{Treatments}

In this experiment, the main treatments comprised: 1) CM in nano-sized particles at $5 \mathrm{t} / \mathrm{ha}$ (nCM5); 2) CM in nanosize particles at $20 \mathrm{t} / \mathrm{ha}(\mathrm{nCM} 20) ; 3) \mathrm{CM}$ in micro-sized particles at $5 \mathrm{t} / \mathrm{ha}$ (mCM5); 4) CM in micro-sized particles at $20 \mathrm{t} / \mathrm{ha}(\mathrm{mCM} 20) ; 5) \mathrm{CM}$ in its natural size at $5 \mathrm{t} / \mathrm{ha}$ (CM5); 6) CM in its natural size at $20 \mathrm{t} / \mathrm{ha}$ (CM20); and 7) Without CM (wCM). Each treatment consisted of 5 subtreatments of chemical fertilizer, including: 1) NPK (urea $100 \mathrm{~kg} / \mathrm{ha}$, triple superphosphate $50 \mathrm{~kg} / \mathrm{ha}$ and $\mathrm{K}$ sulfate $300 \mathrm{~kg} / \mathrm{ha}$ ); 2) NK (urea $100 \mathrm{~kg} / \mathrm{ha}$ and $\mathrm{K}$ sulfate $300 \mathrm{~kg} /$ ha); 3) NP (urea $100 \mathrm{~kg} / \mathrm{ha}$ and triple superphosphate $50 \mathrm{~kg} / \mathrm{ha}$ ); 4) N (urea $100 \mathrm{~kg} / \mathrm{ha}$ ); 5) Without chemical fertilizer (wCF). Each treatment was carried out in three replications, which consisted of 105 plots.
Crop cultivation

The experiments, arranged as a factorial design and replicated three times, was conducted using $1.5 \mathrm{~m} \times 2$ $\mathrm{m}$ experimental plots ploughed to a depth of $30 \mathrm{~cm}$. The land was ploughed and disked before any treatments were applied. Levees were constructed to separate the plots. Where the CM was to be incorporated (nano-, micro- and natural-sized), it was initially applied uniformly as a mulch and then incorporated to a depth of $0.17 \mathrm{~m}$ manually using a spade before drilling. Chemical urea fertilizer was added to the soil in two stages: before cultivation and during flowering. The soybean variety used in this experiment was D.P.X3589. Each plot consisted of four rows, $2 \mathrm{~m}$ long and $40 \mathrm{~cm}$ apart. Irrigation was carried out around 14-28 days with regard to air temperature. Weeds were regularly removed by hand-weeding after planting. Spraying for pests was done once after flowering.

At the end of the growing season, samples were taken from a square meter in the middle of each plot. After the marginal effects and grain yield were removed, 1000 grain weight, number of pods per plant, biological yield, and plant height were measured.

Tissue nutrient concentration

The concentrations of $\mathrm{N}, \mathrm{P}$, and $\mathrm{K}$ in plant shoot material at flowering were determined using a standard digest technique (11). N was measured using Kjeltec, P using a colorimetric method, and $\mathrm{K}$ by flame photometry. Leaf samples were taken from the center of each plot at the soybean flowering stage.

Plant height $(\mathrm{cm})$

Plant height was measured from the base to the top of the plant at the end of cropping.

\section{Number of pods per plant}

The number of pods per plant was measured at the end of the growth period from $1 \mathrm{~m}^{2}$ in the middle of each plot.

Grain yield (kg/ha)

At maturity, the weight of soybeans per square meter was

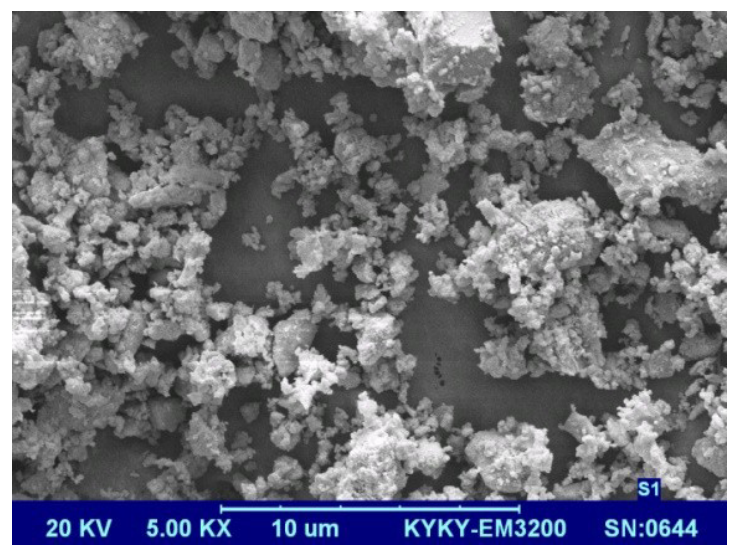

Figure 1. SEM image with magnification $\times 5000$. 
obtained, and then calculated in kilograms per hectare.

\section{Soil properties}

Air-dried soil samples were passed through a 2-mm sieve. Soil organic matter was measured using the WalkleyBlack method (12). Total $\mathrm{N}$ and soil phosphorus were measured by the Kjeldahl and Olsen methods, respectively (13). A pH meter (WTW Inolab pH 720, Germany) and EC meter (cond 720, Germany) were used to determine $\mathrm{pH}$ and electrical conductivity (EC) in saturated extract, respectively. Soil texture was determined using the Bouyoucos method (14). Cation exchange capacity (CEC) was determined using $\mathrm{NH}_{4} \mathrm{OAc} / \mathrm{NaNH}_{4} \mathrm{OAc}$ at 7.0 (15).

\section{Half-life of cattle manure}

The amount of soil organic matter was measured in 6 stages after the manure was added to the soil $(0,11,24$, 48,55 , and 66 weeks). At zero time, the amount of organic matter added to the soil was obtained by dividing the mass of the additive fertilizer ( 5 and $20 \mathrm{t} / \mathrm{ha}$ ) by the soil mass (up to the depth at which fertilizer was mixed with the soil). In subsequent stages, direct sampling was carried out from the depth at which the fertilizer was mixed with the soil $(17 \mathrm{~cm})$. The amount of organic matter was calculated at 0 to 66 weeks and plotted in $y=\ln [\mathrm{A}]_{0}-\mathrm{Kt}$. Then, the slope of the equation line $(\mathrm{K})$ was obtained. By placing it in relation $t_{1 / 2}=0.693 / K$, the half-life of manure was obtained.

\section{Statistical analysis}

The data collected from this experiment was analyzed and compared for statistical differences using the analysis of variance (PROC GLM) method and LSD test, and the software package Statistical Package for the Social Sciences (SPSS) was used to process the analyses.

\section{Results}

The measurements of soil properties before cultivation are shown in Table 1.

According to the results, the soil has a silty clay loam texture and is low in $\mathrm{N}$ and phosphorus content. The levels of organic matter and $\mathrm{K}$ are in a good range, and soil salinity is low.

\section{Half-life of cattle manure}

The analysis of variance showed that the effect of CM on the half-life was significant at a $1 \%$ level. However, the effect of chemical fertilizer and the interaction of cattle and chemical fertilizers were not significant on the halflife.
In Figure 2, the comparison of the mean half-life of CM is shown in various sizes.

The highest mean half-life of CM was observed in the CM20 treatment with a mean of 34.5 weeks and the lowest was in treatment nCM5 with an average of 6.7 weeks (Figure 2).

By increasing the amount of crushing, the nano-sized CM particles had the lowest half-life in the soil followed by the micro-sized particles (Figure 2).

\section{Yield and Yield components}

The averages of the effects of cattle and chemical fertilizers on the number of pods per plant, plant height, 1000 grain weight, grain yield and total biomass are shown in Table 2 . The interaction effects of $\mathrm{CM}$ and chemical fertilizer treatments on the 1000 grain weight, grain yield, and total biomass are shown in Table 3.

\section{Tissue nutrient concentration}

Figure 3 shows the average N, P, and K contents in soybean leaf at flowering stage.

The highest contents of $\mathrm{N}, \mathrm{P}$, and $\mathrm{K}$ in the flowering stage was observed in treatment nCM20 at 5.09\%, 0.47\%, and $2.35 \%$, respectively. The lowest concentrations in the control treatments were $2.58 \%, 0.26 \%$, and $1.45 \%$, respectively.

\section{Discussion}

Number of pods per plant and plant height

The analysis of variance showed that the organic and chemical treatments had a significant effect at a level of $1 \%$ on the number of pods per plant and soybean height. Their interaction was not significant. By adding CM (at each level and size) to each experimental plot, the number of pods per plant was significantly increased compared to the non-manure treatment. The increase in the number of pods per unit area can be attributed to the increased number of nodes and reduced abortion of flower and pods

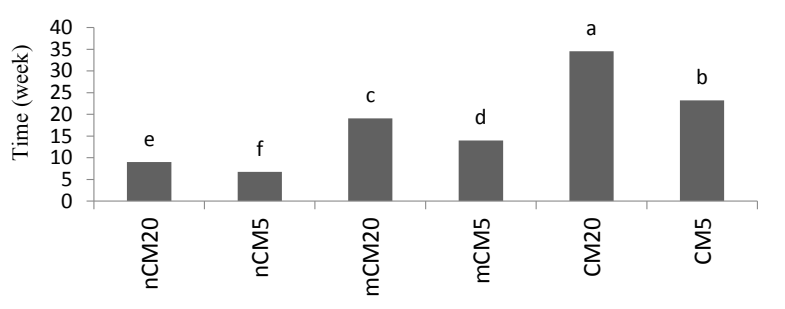

Type of cattle manure (Having at least a common letter shows no significant difference)

Figure 2. Comparison of the mean half-life of cattle manure in soil at nano-, micro-, and natural-sized scales.

Table 1. Soil characteristics of the area before cultivation

\begin{tabular}{cccccccccc}
\hline pH & $\begin{array}{c}\mathrm{EC} \\
\left(\mathbf{d s} / \mathbf{m}^{-1}\right)\end{array}$ & $\begin{array}{c}\text { CEC }(\mathbf{m e q} / \mathbf{1 0 0} \\
\left.\mathbf{g}^{-1}\right)\end{array}$ & $\begin{array}{c}\mathbf{K} \\
(\mathbf{m g} / \mathbf{k g})\end{array}$ & $\begin{array}{c}\mathbf{P} \\
(\mathbf{m g} / \mathbf{k g})\end{array}$ & $\mathbf{N}(\%)$ & OM (\%) & Clay (\%) & Sand (\%) & Silt (\%) \\
\hline 7.6 & 0.8 & 19.2 & 375 & 7.6 & 0.1 & 1.6 & 32.5 & 13.2 & 54.3 \\
\hline
\end{tabular}


Table 2. Effects of treatment applications on average soybean yield

\begin{tabular}{|c|c|c|c|c|c|}
\hline & $\begin{array}{l}\text { 1000-grain } \\
\text { weight (g) }\end{array}$ & $\begin{array}{c}\text { Number of pods } \\
\text { per plant }\end{array}$ & $\begin{array}{l}\text { Plant height } \\
\text { (cm) }\end{array}$ & $\begin{array}{c}\text { Grain yield } \\
\text { (kg/ha) }\end{array}$ & $\begin{array}{c}\text { Biological yield } \\
\text { (kg/ha) }\end{array}$ \\
\hline \multicolumn{6}{|c|}{ Factor A (cattle manure) } \\
\hline nCM20 & $216.6^{\mathrm{a}}$ & $68.2^{\mathrm{a}}$ & $114.5^{\mathrm{a}}$ & $4169.3^{\mathrm{a}}$ & $10254.1^{\mathrm{a}}$ \\
\hline $\mathrm{nCM} 5$ & $210.8^{\mathrm{ab}}$ & $64.9^{b}$ & $111.4^{\mathrm{b}}$ & $3700.7^{b}$ & $9821.8^{b}$ \\
\hline $\mathrm{mCM} 20$ & $212.3^{\mathrm{ab}}$ & $64.2^{\mathrm{b}}$ & $110.8^{b}$ & $3704.2^{b}$ & $9793.5^{b}$ \\
\hline $\mathrm{mCM} 5$ & $210.2^{b}$ & $56.9^{c}$ & $106.1^{\mathrm{c}}$ & $3147.3^{c}$ & $9082.1^{c}$ \\
\hline $\mathrm{CM} 20$ & $210.6^{\mathrm{ab}}$ & $57.2^{c}$ & $105.2^{c}$ & $3165.6^{c}$ & $9094.0^{c}$ \\
\hline CM5 & $210.4^{b}$ & $49.3^{d}$ & $100.8^{\mathrm{d}}$ & $2781.1^{d}$ & $8601.6^{d}$ \\
\hline wCM & $155.4^{c}$ & $36.2^{\mathrm{e}}$ & $92.2^{\mathrm{e}}$ & $2079.8^{e}$ & $8117.6^{e}$ \\
\hline \multicolumn{6}{|c|}{ Factor B (chemical fertilizer) } \\
\hline NPK & $207.2^{\mathrm{a}}$ & $61.7^{\mathrm{a}}$ & $110.1^{\mathrm{a}}$ & $3555.7^{a}$ & $9778^{a}$ \\
\hline NK & $205.6^{\mathrm{a}}$ & $58.4^{\mathrm{b}}$ & $105.1^{\mathrm{c}}$ & $3380.9^{b}$ & $9400^{b}$ \\
\hline NP & $203.7^{\mathrm{ab}}$ & $57.1^{\mathrm{b}}$ & $107.8^{\mathrm{b}}$ & $3299.7^{c}$ & $9327^{b}$ \\
\hline $\mathrm{N}$ & $202.7^{\mathrm{ab}}$ & $55.2^{\mathrm{c}}$ & $105.3^{c}$ & $3133.9^{d}$ & $9067^{c}$ \\
\hline wCF & $199.5^{\mathrm{b}}$ & $51.0^{d}$ & $100.9^{d}$ & $2878.4^{e}$ & $8686^{d}$ \\
\hline
\end{tabular}

due to the increased use of animal manure (16). Among the chemical fertilizer treatments, the NPK treatment showed the highest number of pods per plant (Table 2). A comparison of the averages of the effects of CM and chemical treatments showed that NPK chemical fertilizer with a mean value of 61.7 pods per plant had a higher yield than CM with a mean pod number of 53.2 pods per plant. Organic manures alone cannot meet the heavy demands of nutrients in intensive soybean production due to their limited availability and restricted nutrient supply (10). By crushing $\mathrm{CM}$, however, the performance of $\mathrm{nCM}$ and $\mathrm{mCM} 20$ showed a significant increase compared to the NPK treatment (Table 2). The range of chemical reactions is much higher for nanoscale materials than for other materials. In nanoscale materials, a high percentage of atoms is placed on the surface of the material, so the probability of atoms colliding with each other increases, and the reactivity of the material increases (17). Nanoscale materials are strongly affected by their physical and chemical properties, and the time required for decomposition is significantly reduced by microorganisms (18). The highest number of pods per plant in the CM and chemical treatments was related to the nCM20 treatment with 68.2 pods.

Among the CM treatments, the highest mean height (114 $\mathrm{cm}$ ) was related to the nCM20 treatment. The increased height due to manure can be attributed to greater plant growth during the vegetative period (19). Among the chemical fertilizer treatments, the greatest height of 110 $\mathrm{cm}$ was related to NPK, and the lowest was observed in the non-chemical fertilizer treatment with a height of $100.9 \mathrm{~cm}$.

Grain yield, biological yield, 1000-grain weight

The results of analysis variance showed that the effects of different fertilizer treatments and their interactions had a significant effect ( $1 \%$ and $5 \%$, respectively) on grain yield and biological yield. With regard to the significance of the interaction between CM and chemical fertilizers, the comparison of mean interactions was obtained for each treatment (Table 3). The highest yield was related to the treatment of nCM20+npk with $4380 \mathrm{~kg} \mathrm{ha}^{-1}$ (Table 3); the lowest yield was related to the control treatment (without fertilizer). The cutting of interactions showed that the effect of chemical fertilizers on each level of $\mathrm{CM}$ was significant at the level of $1 \%$. The use of chemical fertilizers plus CM in all treatments had a positive and significant effect on yield at the level of $1 \%$ (Table 3). However, this yield increase was not the same for all CM treatments at different sizes and levels (Table 3). On average, the $\mathrm{nCM}, \mathrm{mCM}$, and $\mathrm{CM}$ treatments increased $13.8 \%$, $19.51 \%$, and $24.91 \%$, respectively, due to the increase in NPK fertilizers (Table 3 ). In fact, the effect of chemical fertilizer on yield increase was reduced in smaller sizes of CM. Nano-sized fertilizers reduced the dependence of the plant on nutrients supplied through chemical fertilizers and increased the amount of absorbed nutrients by either increasing the rate of degradation or creating conditions that increase the availability of nutrients. The percentage of yield was increased by the addition of NPK fertilizers by $16 \%, 21.22 \%$, and $26.80 \%$ at levels of $5 \mathrm{t} / \mathrm{ha}$ of the treatments $\mathrm{nCM}, \mathrm{mCM}$, and $\mathrm{CM}$, respectively, while at levels of $20 \mathrm{t} / \mathrm{ha}$, it was increased by $11.16 \%, 17.8 \%$, and $23.03 \%$, respectively. In fact, the effect of chemical fertilizer was further reduced by increasing the level of applied organic fertilizer from 5 to $20 \mathrm{t} / \mathrm{ha}$. Therefore, by increasing the amount of grinding and the amount of CM used, a more complete alternative to chemical fertilizers can be provided. It is possible to provide a more complete alternative to chemical fertilizers by increasing the amount of crushing and the use of CM.

The effects of interactions between chemical and organic 
Table 3. Comparison of interaction effects of $\mathrm{CM}$ and chemical fertilizer treatments

\begin{tabular}{|c|c|c|c|c|}
\hline Treatments & & $\begin{array}{l}\text { 1000-grain } \\
\text { weight (g) }\end{array}$ & $\begin{array}{c}\text { Grain yield } \\
\text { (kg/ha) }\end{array}$ & $\begin{array}{c}\text { Biological } \\
\text { yield (kg/ha) }\end{array}$ \\
\hline \multirow{5}{*}{ nCM20 } & NPK & $229.9^{a}$ & $4380^{\mathrm{a}}$ & $10983^{a}$ \\
\hline & NK & $210.8^{\mathrm{bcd}}$ & $4270^{\mathrm{ab}}$ & $10400^{b}$ \\
\hline & NP & $216.5^{a b c}$ & $4203^{b c}$ & $10325^{b}$ \\
\hline & $\mathrm{N}$ & $211.1^{\mathrm{bcd}}$ & $4102^{\text {cd }}$ & $9990^{\text {cd }}$ \\
\hline & - & $215^{\mathrm{cd}}$ & $3890^{\text {ef }}$ & $9570^{\mathrm{gh}}$ \\
\hline \multirow{5}{*}{$\mathrm{mCM} 20$} & NPK & $198.9^{d}$ & $4040^{d}$ & $10289^{b c}$ \\
\hline & NK & $221.7^{\mathrm{ab}}$ & $3840^{\mathrm{fg}}$ & $9900^{d-f}$ \\
\hline & NP & $221.4^{\mathrm{ab}}$ & $3769^{\mathrm{fg}}$ & $9870^{\mathrm{d}-\mathrm{g}}$ \\
\hline & $\mathrm{N}$ & $211.2^{\mathrm{bcd}}$ & $3550^{h}$ & $9687^{\mathrm{d}-\mathrm{g}}$ \\
\hline & - & $208.5^{b c d}$ & $3320^{j}$ & $9219^{i}$ \\
\hline \multirow{5}{*}{$\mathrm{CM} 20$} & NPK & $207.7^{c d}$ & $3547^{h}$ & $9700^{d-g}$ \\
\hline & NK & $211.6^{\mathrm{bcd}}$ & $3320^{j}$ & $9289^{\text {hi }}$ \\
\hline & NP & $215.4^{b c}$ & $3225^{\mathrm{jk}}$ & $9200^{i}$ \\
\hline & $\mathrm{N}$ & $209.6^{\mathrm{bcd}}$ & $3005^{\mathrm{Im}}$ & $8800^{j}$ \\
\hline & - & $208.8^{\mathrm{bcd}}$ & $2730^{\circ}$ & $8479^{k l}$ \\
\hline \multirow{5}{*}{ wCM } & NPK & $166.8^{e}$ & $2301^{p}$ & $8304^{1-n}$ \\
\hline & NK & $165.1^{\mathrm{ef}}$ & $2274^{p}$ & $8124^{\mathrm{m}-\mathrm{o}}$ \\
\hline & NP & $152^{\mathrm{fg}}$ & $2033^{9}$ & $8022^{\text {no }}$ \\
\hline & $\mathrm{N}$ & $151.2^{\mathrm{g}}$ & $1983^{9}$ & $8170^{1-0}$ \\
\hline & - & $142^{\mathrm{g}}$ & $1807^{r}$ & $7968^{\circ}$ \\
\hline \multirow{5}{*}{ nCM5 } & NPK & $216.5^{\mathrm{abc}}$ & $4000^{\text {de }}$ & $10323^{b}$ \\
\hline & NK & $206.7^{c d}$ & $3810^{\mathrm{fg}}$ & $9982^{c-e}$ \\
\hline & NP & $203.6^{c d}$ & $3751^{g}$ & $9811^{\mathrm{d}-\mathrm{g}}$ \\
\hline & $\mathrm{N}$ & $216.9^{a b c}$ & $3582^{h}$ & $9673^{\mathrm{e}-\mathrm{g}}$ \\
\hline & - & $210.6^{\mathrm{bcd}}$ & $3360^{\mathrm{ij}}$ & $9320^{\text {hi }}$ \\
\hline \multirow{5}{*}{ mCM5 } & NPK & $216.5^{a b c}$ & $3490^{\mathrm{hi}}$ & $9650^{f g}$ \\
\hline & NK & $213.1^{b c}$ & $3250^{\mathrm{jk}}$ & $9300^{\mathrm{hi}}$ \\
\hline & NP & $205.9^{c d}$ & $3230^{\mathrm{jk}}$ & $9310^{\text {hi }}$ \\
\hline & $\mathrm{N}$ & $210.9^{b c d}$ & $3015^{\operatorname{lm}}$ & $8804^{j}$ \\
\hline & - & $204.9^{c d}$ & $2750^{\text {no }}$ & $8345^{\operatorname{lm}}$ \\
\hline \multirow{5}{*}{ CM5 } & NPK & $214.3^{\mathrm{bc}}$ & $3130^{\mathrm{kl}}$ & $9200^{i}$ \\
\hline & NK & $210.4^{\mathrm{bcd}}$ & $2900^{m}$ & $8807^{j}$ \\
\hline & NP & $211.7^{\mathrm{bcd}}$ & $2885^{m n}$ & $8756^{\mathrm{jk}}$ \\
\hline & $\mathrm{N}$ & $208.4^{\mathrm{bcd}}$ & $2700^{\circ}$ & $8345^{\operatorname{lm}}$ \\
\hline & - & $207.2^{\text {cd }}$ & $2290^{p}$ & $7899^{\circ}$ \\
\hline
\end{tabular}

NPK (urea 100 , triple superphosphate 50 , and potassium sulfate 300 ), NK (urea 100 and potassium sulfate 300), NP (urea 100 and triple superphosphate 50), N (urea 100), - (Without chemical fertilizer). Unit for all $=(\mathrm{kg} / \mathrm{ha})$.

* Having at least a common letter shows no significant difference. fertilizers on dry matter yield were significant at a level of $5 \%$. The highest dry matter yield was related to the nCM20+NPK treatment with $10983.6 \mathrm{~kg} \mathrm{ha}^{-1}$ (Table 3). The lowest dry matter yield was related to the control treatment (without fertilizer) with $7968 \mathrm{~kg} \mathrm{ha}^{-1}$. One of the main reasons for the increase in soybean yield was the increase in dry matter (10).

Tissue nutrient concentration

A comparison of the mean $\mathrm{N}, \mathrm{P}$, and $\mathrm{K}$ concentrations in plants showed that treatments with $20 \mathrm{t} /$ ha had higher rates than treatments of $5 \mathrm{t} / \mathrm{ha}$.

The nCM treatments showed the highest levels of $\mathrm{N}, \mathrm{P}$, and $\mathrm{K}$ in plant tissue compared to the $\mathrm{mCM}$ and $\mathrm{CM}$ treatments. The quicker mineralization process of $\mathrm{nCM}$ than $\mathrm{CM}$ in soil and the resultant provision of proper $\mathrm{N}$ prior to the creation of the node in the soybean root can be an important reason for the increase in soybean leaf $\mathrm{N}$. $\mathrm{N}$ consumption improves performance when it is given to the plant during the early stages of growth (10).

Among the chemical fertilizer treatments, the NPK treatment showed the highest concentrations of N, P, and $\mathrm{K}$ in the plants; however, their concentrations were lower in the NPK treatment than in the nano-sized treatment. It is likely that the retention time of $\mathrm{nCM}$ was longer in the porous medium than that of the soluble fertilizers, and thus, the former supplied more nutrients to the plants than chemical fertilizers. While a chemical nutrients fertilizer hits the soil all at once and does not allow sufficient time for plant uptake, nanoparticles provide a slow release of nutrients for an extended period of time (9).

\section{Conclusion}

This research indicated that $\mathrm{nCM}$ could be used as a fertilizer to enhance crop yields and biomass production. The nCM treatments showed much higher yields than those of chemical fertilizers and CM. Due to their halflife in soil, the plants were allowed to absorb nutrients for a longer period of time than completely soluble chemical fertilizers. The nanoparticle-based fertilizer has two major advantages over chemical fertilizers: it does not release nutrients as quickly as chemical fertilizers, and the loss of

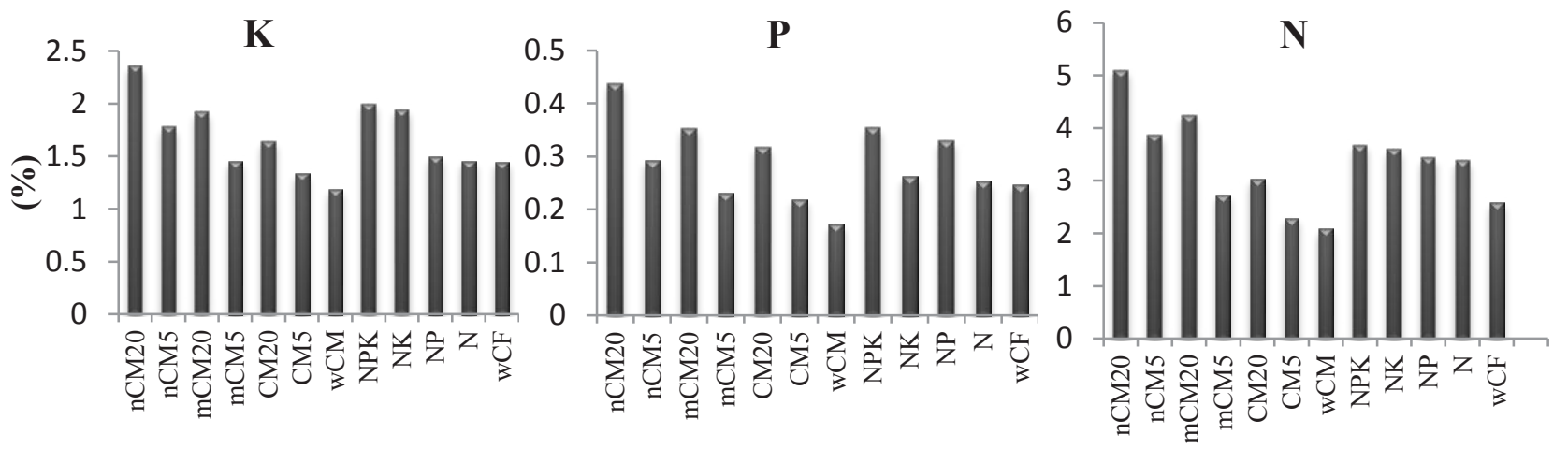

Figure 3. Effects of treatment applications on shoot nutrient concentration. 
nutrients from soil is low. The slow and steady release of nutrients allows plants to continuously take up nutrients as they grow. On the other hand, organic forms of nutrients (e.g., CM) have also been attempted as nutrient fertilizers where the nutrients are locked in an organic form and are less effective in providing nutrients at the critical time due to the low decomposition rate (when the plants are in need).

In fact, nanoparticles play an intermediate state between $\mathrm{CM}$ and chemical fertilizers. The nCM has eliminated the defects of both CM and chemical fertilizer. Attributable to their nanoscale size and nutrients release kinetics, CM nanoparticles are increasingly advocated as a promising nutrient fertilizer.

\section{Acknowledgments}

This research was funded by Gorgan University of Agricultural Sciences and Natural Resources (Iran).

\section{Ethical issues}

Authors report no ethical issues in the performance of this study.

\section{Competing interests}

The authors declare that they have no conflicts of interest to declare.

\section{Authors' contributions}

All authors were involved in all stages of the article. On behalf of the co-authors, the corresponding author bears full responsibility for this submission.

\section{References}

1. Cooper RL. A delayed flowering barrier to higher soybean yields. Field Crops Res 2003; 82(1): 27-35. doi: 10.1016/ S0378-4290(03)00003-0.

2. Specht JE, Hume DJ, Kumudini SV. Soybean yield potential-a genetic and physiological perspective. Crop Sci 1999; 39(6): 1560-70. doi: 10.2135/cropsci1999.3961560x.

3. Singh G, editor. The Soybean: Botany, Production and Uses. Wallingford, Oxfordshire: CABI (Centre for Agriculture and Biosciences International); 2010. doi: 10.1079/9781845936440.0000.

4. Chen JH, Wang YJ, Zhou DM, Cui YX, Wang SQ, Chen YC. Adsorption and desorption of $\mathrm{Cu}(\mathrm{II}), \mathrm{Zn}(\mathrm{II}), \mathrm{Pb}(\mathrm{II})$, and $\mathrm{Cd}(\mathrm{II})$ on the soils amended with nanoscale hydroxyapatite. Environ Prog Sustain Energy 2010; 29(2): 233-41. doi: 10.1002/ep.10371.

5. Handley-Sidhu S, Renshaw JC, Moriyama S, Stolpe B, Mennan C, Bagheriasl S, et al. Uptake of $\mathrm{Sr}^{2+}$ and $\mathrm{Co}^{2+}$ into biogenic hydroxyapatite: implications for biomineral ion exchange synthesis. Environ Sci Technol 2011; 45(16): 6985-90. doi: 10.1021/es2015132.

6. Zhang Z, Li M, Chen $\mathrm{W}$, Zhu S, Liu N, Zhu L. Immobilization of lead and cadmium from aqueous solution and contaminated sediment using nanohydroxyapatite. Environ Pollut 2010; 158(2): 514-9. doi: 10.1016/j.envpol.2009.08.024.

7. Liu R, Lal R. Synthetic apatite nanoparticles as a phosphorus fertilizer for soybean (Glycine max). Sci Rep 2014; 4: 5686. doi: 10.1038/srep05686.

8. Montalvo D, McLaughlin MJ, Degryse F. Efficacy of hydroxyapatite nanoparticles as phosphorus fertilizer in andisols and oxisols. Soil Sci Soc Am J 2015; 79(2): 551-8. doi: 10.2136/sssaj2014.09.0373.

9. Wang D, Jin Y, Jaisi DP. Cotransport of hydroxyapatite nanoparticles and hematite colloids in saturated porous media: Mechanistic insights from mathematical modeling and phosphate oxygen isotope fractionation. J Contam Hydrol 2015; 182: 194-209. doi: 10.1016/j. jconhyd.2015.09.004.

10. Hany A. El-Shemy. Soybean physiology and biochemistry. InTech; 2011.

11. Westerman RL. Soil Testing and Plant Analysis. Wisconsin, USA: Soil Science Society of America Inc; 2005.

12. Nelson DW, Sommers L. Total Carbon, Organic Carbon, and Organic Matter. Madison, USA: ASA-SSSA; 1982.

13. Olsen SR, Cole CV, Frank S,Dean LA. Estimation of Available Phosphorus in Soils by Extraction with Sodium Bicarbonate. Washington DC: United States Department of Agriculture; 1954.

14. Bouyoucos GJ. Hydrometer method improved for making particle size analyses of soils. Agron J 1962; 54(5): 464-5. doi: 10.2134/agronj1962.00021962005400050028x.

15. Sumner M, Miller WP, Sparks DL, Page AL, Helmke PA, et al. Cation exchange capacity and exchange coefficients. In: Methods of Soil Analysis. Part 3: Chemical Methods. Madison, Wisconsin, USA: Soil Science Society of America Inc; 1996. p. 1201-29.

16. Gliessman RS. Agroecology: The Ecology of Sustainable Food Systems. 2en ed. Boca Raton, FL. USA: CRC Press; 2006.

17. Karimzadeh F, Ghasemali A, Salemizadeh S. Nanomaterials: Properties, Production and Application. Isfahan: Iranian Students Booking Agency; 2012. [In Persian].

18. Wang CB, Wang DL, Chen WX, Wang YY. Tribological properties of nanostructured $\mathrm{WC} / \mathrm{CoNi}$ and $\mathrm{WC} / \mathrm{CoNiP}$ coatings produced by electro-deposition. Wear 2002; 253(5/6): 563-71. doi: 10.1016/S0043-1648(02)00173-4.

19. Reddy DD, Rao AS, Rupa TR. Effects of continuous use of cattle manure and fertilizer phosphorus on crop yields and soil organic phosphorus in a Vertisol. Bioresour Technol 2000; 75(2): 113-8. doi: 10.1016/S0960-8524(00)00050-X. 